\title{
A LINGUAGEM GESTUAL NO TEATRO DE BRECHT
}

\author{
Willi Bolle
}

No ensaio "Sobre poesia sem rimas com ritmos irregulares" (1939), Bertolt Brecht explica a elaboração de uma nova técnica de linguagem, tanto do verso, quanto da prosa, que ele chama gestual. (1) Isto significa que a expressão verbal deve impregnar-se inteiramente do gestus da pessoa que fala. Assim, a frase bíblica "Arranca o olho que te aborrece" pode ser expressa com maior força gestual da seguinte maneira: "Se teu olho te aborrecer, arranca-o!" De fato, Lutero, tradutor da Bíblia para o Alemão e empenhado em captar os fatos linguiísticos "na boca do povo", optou por esta formulação.

A referência à figura do Reformador e a utilização do termo latino gestus, empregado por Cícero no sentido de "atitude do corpo", em particular "gestos do ator ou do orador" são significativas: Brecht focaliza a linguagem na sua função pública. No mesmo sentido vão suas observações sobre os gritos dos vendedores de jornais e os coros improvisados por manifestantes operários nas ruas de Berlim. Como uma das circunstâncias históricas dessa nova rítmica, gestual, transparece a percepção de fortes dissonâncias sociais.

A linguagem gestual aparece como um dos traços mais marcantes da obra de Brecht, como um instrumento de expressão que atinge amplas dimensões comunicativas e que subjaz não apenas às suas peças de teatro, mas também à produção poética e aos escritos teóricos. Este trabalho se propõe sistematizar as informações teóricas de Brecht sobre linguagem gestual, sem a intenção de estabelecer um sistema normativo. O conjunto das definições é visto com relação a dois momentos históricos: 1) as circunstâncias da gênese do teatro épico, na Alemanha dos anos 1920 a $1933 ; 2$ ) a atuação da dramaturgia brechtiana na teoria estética, a partir dos anos 1950 .

(1) - "Uber reimlose Lyrik mit unregelmässigen Rhythmen", in: Gesammelte Werke 19, Suhrkamp Frankfurt/M., 1975, p. 398. 


\section{Definições preliminares}

A principal fonte de informaçōes sobre a teoria brechtiana da linguagem gestual são seus Escritos sobre o Teatro (2) E indispensável definir preliminarmente três termos-chave, semelhantes entre si e que, no entanto, não se confundem: Gestik - Geste - Gestus.

Brecht estabelece uma separação entre Gestik (comunicação por meio de gestos) e Pantomime (pantomima); esta expressa tudo sem palavras, mesmo a fala, e é considerada exclusivamente como manifestação artística, ao mesmo titulo que a ópera, o espetáculo teatral, a dança (ST 6: 212) (3) A proposta de Brecht consiste em estudar a comunicação por meio de gestos tal como é encontrada na vida cotidiana, o teatro funcionando como uma espécie de laboratório.

Elemento constitutivo da Gestik é o gesto individual (Geste) (ST 6: 213) Expresso em lugar de palavras, sua compreensão é dada pela convenção, como (na nossa cultura) o curvar afirmativamente a cabeça. Brecht distingue gestos ilustrativos, como os que descrevem o tamanho de um pepino ou a curva de um carro de corrida, e gestos que manifestam atitudes emotivas, tais como desprezo, tensão, perplexidade.

Com o gesto não deve ser confundido o Gestus. Brecht adverte: "Falando de Gestus, não se pretende falar da gesticulação (Gestikulieren); não se trata de movimentos das mãos no intuito de frisar ou explicar a fala, mas sim de atitudes gerais. Uma linguagem é gestual (gestisch) quando se fundamenta no gestus, quando revela determinadas atitudes do indivíduo que fala, assumidas perante outros indivíduos" (ST 3: 281) O gestus, portanto, é signo de interação social. Assim, por exemplo, um homem que vende um peixe manifesta o gestus de vender; um homem redigindo seu testamento, uma mulher atraindo um homem, um policial batendo num homem, um homem pagando dez homens - em tudo isso está um gestus social (ST 4: 31) Outra característica do gestus é sua complexidade: seus elementos constitutivos podem ser gestos, expressões mímicas ou palavras, simultânea ou separadamente. As palavras podem estar contidas nos gestos ou na mímica, como acontece no filme mudo. Inversamente, um gestus pode ser expresso unicamente por palavras, por exemplo, num discurso de rádio ou de telefone; neste caso, uma determinada postura ou mímica - uma reverência humilde, um tapinha nas costas - se projeta dentro das palavras e nelas pode ser detectada. E

(2) - Schriften zum Theater 1-7, Suhrkamp, Frankfurt/M., 1963-1964.

(3) - Schriften zum Theater 6, p. 212. 
mais: palavras podem ser substituídas por outras palavras, gestos por outros gestos, sem que haja por isso uma mudança do gestus (ST 4: 32)

Não interessa a Brecht o estudo isolado do sistema dos signos gestuais, mas a sua interação com outras séries semióticas. Mesmo assim, a onipresença do elemento gestual marca uma preponderância: a projeção do signo corporal dentro da linguagem verbal. A essa dimensão intersemiótica Brecht dá o nome de linguagem gestual (4)

\section{Teoria brechtiana da arte}

As definiçōes anteriores só ganham seu sentido pleno no contexto da praxis teatral de Brecht, vista no contexto mais amplo de sua teoria da arte. O condicionamento da produção artística e literária pelos processos históricos e pelas forças dominantes nem sempre ficou tão patente como no caso da literatura alemã de exílio (1933-1945); com efeito, a parte mais importante das peças e dos escritos teóricos de Brecht nasceu naqueles anos, fora da Alemanha. Sua estética não se colocou sob o signo de valores eternos, mas em oposição contra uma realidade histórica: o fascismo nacional socialista. Na época, Brecht não se alinhou, como outros escritores de esquerda, nas fileiras do realismo socialista. Na discussão com Lukács, refutou as recomendações de tomar como modelo os romancistas realistas burgueses do século 19, argumentando que sobre formas literárias era preciso interrogar não a estética, mas sim a realidade: "A nossa estética e a nossa ética derivam das necessidades da luta" (GW 19: 349)

Em outro ponto, as teorias de Brecht e de Lukács se aproximam. O autor da "Sociologia do drama moderno" (1909) se interessava primordialmente pela análise das interrelações entre formas de vida e formas de arte; (6) Brecht, no ensaio sobre o teatro amador, aponta uma interrelação semelhante: a arte teatral seria, por assim dizer a mais humana, a mais geral de todas as artes, a mais frequientemente praticada, não apenas no palco, mas também na vida (ST 4: 64)

(4) - A comunicação por meio de gestos no teatro de Gerhart Hauptmann foi estudada por Erwin Theodor (Recursos expressivos na evolução da obra dramática de Gerhart Hauptmann, Boletim No 295 da FFCL da USP, 1964, p. 39-61 e passim), sob o nome de linguagem gesticulante, termo esse consagrado pelo dicionário. No caso de Brecht, no entanto, a distinção explicitamente feita por ele entre Gestikulieren e Gestus/gestische Sprache me fez chamar esta última de linguagem gestual.

(5) - "Uber realistische Schreibweise" (1938), in: Gesalmmelte Werke 19 , p. 349.

(6) - G. Lukács, "Zur Soziologie des modernen Dramas", in: Schrifte zur Literatursoziologie, ed. P. Ludz, Luchterhand, Neuwied, 5 1972, p. 261. 
Brecht lembra a maneira teatral como se processa a educação do ser humano. A criança, muito antes de ser provida de argumentos, apreende de maneira teatral como tem que se comportar; por exemplo, quando é permitido rir ou quando se deve rir. O caso do adulto não é diferente, sua educação nunca cessa; são processos teatrais que formam os caracteres, o homem copiando gestos, mímica, maneiras de falar (ST 4: 63-64) Aqui, Brecht parece seguir a linha do pensamento de Lukács, embora com uma conceituação menos rigorosa, o que o faz passar de um domínio para o outro com maior flexibilidade.

Para o dramaturgo, as fronteiras entre formas de arte e formas de vida se diluem através da categoria do espetáculo. Brecht considera que o palco desempenha quase a função de um desfile de modas: apresentam-se não os mais recentes vestidos, mas as mais recentes maneiras de comportamento; não se mostram as modas, mas os modos. (7) A apresentação no palco, na tela de cinema (ou televisão) é sempre também sugestāo de valores: o espectador é "levado a compartilhar determinados sentimentos de personagens que aparecem no palco, e assim a aprová-los como sentimentos genericamente humanos, óbvios e naturais" (ST 4: 61) - o que nem sempre é o caso. Brecht narra a experiência de um filme sobre a luta dos ingleses na India, em que o espectador é levado a simpatizar com a causa imperialista, em conseqüência de uma hábil manipulação cinematográfica que expõe os hindus defendendo sua terra a um irresistível ridículo (ST 4: 61-62) Portanto, a forma, enquanto elemento sociológicohistórico, torna-se significativa para a estrutura de valor (8)

No ensaio "Uber die Theatralik des Faschismus" (1939/1940), Brecht propõe examinar a técnica teatral usada pela classe dominante, "pelos opressores do nosso tempo": estudar como eles representam, não nos seus teatros, mas nas ruas e em suas moradias, nas salas de conferências e nas chancelarias diplomáticas. Entende-se por representação o seu comportamento não apenas como algo exigido diretamente pelos seus atos, mas como atuação consciente com o intuito de fazer passar ante um público as próprias ações e os próprios negócios como óbvios e exemplares (ST 5: 88) Com a visão profissional aguçada para toda forma de espetáculo, Brecht percebe que as forças históricas atuantes não são apenas de ordem econômica e social, mas também de ordem estética. Enquanto Lukács, seguindo a linha de um materialismo histórico ortodoxo, se encaminha para o estudo das

(7) - "es wird nicht gezeigt, was man trägt, aber wie man sich beträgt" (ST 4: 63).

(8) - Cf. Lukács 1972, p. 262. 
influências das estruturas econômicas e das lutas de classes (infraestruturas) sobre as formas literárias e artísticas (superestruturas), Brecht propõe uma nova perspectiva: aponta a existência de estruturas estéticas (no caso, técnicas teatrais) não sobrepostas, mas imanentes às estruturas do poder (a "linguagem" do fascismo, no sentido mais amplo do termo)

Uma das categorias da estética dominante é a da representação - uma exibição de representação política, ligada tradicionalmente a atributos como insígnias, hábitos, retórica, gestus. Quem tinha um senso agudo para isso era, na Alemanha nos anos 1920 e 1930, o chefe do partido nacional-socialista. Como se sabe, Hitler tomou aulas de técnica de declamação e de expressão corporal com o ator Basil em Munique, aprendendo, por exemplo, a caminhar com passos de herói, a cruzar os braços de maneira impositiva, a se dar ares de superioridade (ST 5: 89) (9) O aprendiz de ator logo se pôs a desenvolver um papel individual, de funesta projeção histórica, começando a forjar a sua imagem pública: o amador de música, fruidor de autêntica música alemã; o soldado desconhecido da Guerra Mundial: o Volksgenosse dando alegremente sua contribuição.

Diz Brecht que numa comemoração da batalha de Tannenberg, Hitler é o único, entre os representantes oficiais, capaz de expressar do maneira mais ou menos convincente, o luto pelas vítimas da batatha de 1914 (ST 5: 91-92) Atitudes como esta foram tomadas conscientemente em lugares públicos, ante o microfone e a câmera, reprodutores e amplificadores do gestus para o país inteiro. $\mathrm{O}$ ato público é transformado em publicidade, o político, "ao invés de representar o povo, representa ante o povo" (10)

Outra cateogria é a dramatização do discurso. Brecht propõe-se examinar a maneira de Hitler agir nos grandes discursos que prepararam ou fundamentaram seus massacres, estudá-lo quando quer levar o público a colocar-se no lugar dele (sich einfühlen) e a dizer: Sim, nós também agiríamos assim! Nesses momentos, apresenta-se como "ser humano", querendo persuadir o público a conceber suas atitudes como simplesmente humanas, naturais, e a dar-lhe espontaneamente seus aplausos. Cria-se uma empatia do público em relação ao orador. Quais as técnicas que a provocam? Antes de mais nada, a auto-dramatização. Para facilitar a empatia, o orador-ator coloca-se a si pró-

(9) - A importância da expressão corporal para os políticos é atestada atualmente por J. Fast, Body Language, Evans \& Co., New York, 1970, p. $181-185$.

(10) - Cf. J Habermas, Strukturwandel der Öffentlichkeit, Luchterhand Neuwied, 5 1972, p. 20. 
prio em estados de alto teor emotivo, em modos de sentir acessíveis também ao homem comum. Ele é um personagem singular, um herói no drama que tenta fazer o público dizer o que ele diz, sentir o que ele sente. Para tal, ele próprio tem que sentir intensamente, o que consegue falando como particular para particulares; suas lutas contra outros políticos são transpostas para o plano de brigas individuais. Em tudo isso, o auditório - que é um público de simples espectadores, um público de aclamação - tem facilidade de segui-lo emotivamente, participar dos seus triunfos, adotar as suas atitudes (ST 5: 92-95)

Evidentemente, as técnicas de propaganda política são bem mais complexas. (11) Aqui importa dar uma idéia do gestus estético implícito na propaganda fascista, pelo enfoque de algumas técnicas teatrais. A análise de Brecht se serve conscientemente de vocabulário dramatúrgico: falando de Hitler, fala em ator e cena, em meios artísticos e recursos dramatúrgicos, em uma forma de teatro muito interessante e mesmo exemplar A arte volta a ser tecné.

Tal o líder, tais os seguidores: "Não há dúvida que os fascistas evidenciam um comportamento marcadamente teatral. Eles têm um sentido especial para isso. Eles próprios falam de encenação e foram buscar uma quantidade de efeitos diretamente no teatro: os holofotes e a música de fundo, os coros e as surpresas" (ST 5: 89) (12) Porém, através das encenações e dos artifícios transparece o gestus social dos nazistas, por Brecht assim caracterizado: "A pompa dos fascistas, considerada simplesmente como pompa, tem um gestus vazio, o gestus da pompa em si, um fenômeno sem qualidade; ao invés de pessoas andando, há pessoas marchando, alguma rigidez, muito colorido, peitos cheios de autoconfiança ostensiva, etc.; tudo isso poderia ser ainda o gestus de um divertimento para o povo, algo inócuo,

(11) - Como exemplo de análise detalhada, mostrando mecanismos de psicologia social, técnicas retóricas e de sugestão de massas, ver $\mathrm{Th}$. W. Adorno sobre os discursos do líder fascista norte-ame-icano Martin Luther Thomas in: Studien zum autoritären Charakter, Shurkamp, 1973, p. 360-483.

(12) - Poderiam ser acrescentados numerosos outros elementos, como as bandeiras, os símbolos, os emblemas, os unifo:mes, as formaçōes coreográficas, as tochas, os fogos de artifício, etc. Um exemplo condensado de encenação propagandística é o filme Triumph des Willens (Triunfo da Vontade), documento do Congresso do Partido nacional-socialista, de setembro de 1934, produzido por ordem de Hitler e reaizado por Leni Riefensthal. Não se trata de simples documentário, nem de simples reunião política, mas de um congresso encenado como uma "grande festa política nacional" e cuidadosamente preparado como show para a gravação cinematográfica. O filme foi re-exibido durante o seminário "Cinema e propaganda - o filme nacional-socialista" realizado no Instituto Goethe de São Paulo, em agosto de 1975. 
algo puramente factual. Mas, no momento em que eles pisam em cima de cadáveres, surge o gestus social do fascismo" (ST 3: 284)

A réplica à estetização da política é a politização da arte. (13) A obra de Brecht é marcada por estar dialética. Ele observou como a arte teatral tradicional, baseada na empatia, foi neutralizada não no palco, mas nas encenações da propaganda nacional-socialista, que a alienou e a assimilou a tal ponto que sua utilização posterior constitui, em termos de criação artística, um flagrante anacronismo e, em termos políticos, uma conivência ideológica. A arte reverte em ideologia no exato momento em que se coloca lado a lado com o Poder ou quando é absorvida por ele. (14) A Weltanschauung nacional-socialista forneceu o exemplo histórico de uma Ideologia que se apresenta como Estética, em que os atos políticos são "espetáculos artísticos" e cujo ponto culminante é o chefe do governo laureado com o título de "maior dos artistas" (15)

O teatro épico, concebido como análise e crítica do gestus ideológico dominante, desmascarava tais encenações como as de uma estética política ANESTESIANTE.

\section{$A$ função do teatro épico e a questão do material}

A função do teatro, segundo Brecht, consiste em entregar ao público a realidade como algo manipulável (ST 4: 273) Isto significa: desenvolver no espectador a consciência de linguagem, a consciência do gestus social. O teatro épico é interessado principalmente em experimentos com os comportamentos que permitem tirar conclusões sobre as condições sociais e que são significativos do ponto de vista da história social.

Quem configura tais gestos não é apenas o "indivíduo mundialmente histórico", no sentido de Hegel e Lukács, (16) mas homens comuns, anônimos, em acontecimentos cotidianos, repetidos aos milhões; seus atos são apresentados no teatro épico como historicamente não menos significativos que as palavras e os efeitos (res gestae) dos generais e estadistas dos manuais escolares (ST II: 181)

(13). - Cf. W Benjamin, Das Kunstwerk im Zeitalter seiner technischen Reproduzierbarkeit, Suhrkamp, Frankfurt/M., 1972, p. 51 .

(14) - Cf. a facilidade de assimilação da estética futurista de um Marinetti pelos fascismos italiano e alemão.

(15) - Cf. o retrato irônico de Brecht: "Der grösste aller Künstler" (1938), GW 18: 254-256.

(16) - Cf. G. Lukács, "Historischer Roman und historisches Drama" (1936/37), in: Schriften ..., p. 193-194. 
O primeiro passo do trabalho do ator (e do autor) consiste em colher o material gestual, e o pressuposto básico é a arte de observação, ilustrada no poema "Discurso para os atores-operários dinamarqueses sobre a arte da observação" (ST V: 256-263) Onde colher a matéria prima? 1) Na vida cotidiana, entre os homens vivos: no local de trabalho, nas moradias, no bairro, na rua, nos meios de transporte, nas lojas, etc.: "Artistas,. procurem de vez em quando o teatro que se passa na rua. $O$ teatro cotidiano, feito por milhares, sem glória, mas tão vivo, terreno, alimentado pelo convívio dos homens. Eis a vizinha imitando o proprietário, ela mostra com precisão sua torrente de palavras, disfarce para desviar a conversa do cano de água que rebentou" (ST V: 251)

2) Nos meios de comunicação de massa, "nas imagens da tela e nos jornais" (ST V: 256) Um exemplo: a personagem Ângelo Iberin em Cabeças redondas e cabeças pontudas não recebeu traços fisionômicos semelhantes a Hitler, mas foram utilizados alguns gestos colhidos em material fotográfico; em particular a maneira de Iberin tratar o microfone (cena 7): o ator mostrou a relação quase erótica do orador para com aquele instrumento (ST IV: 96-97) Outro exemplo é uma representação de Helene Weigel na terceira cena de Mãe Coragem: a expressão de dor pela perda do filho, a boca aberta sem gritar, as mãos crispadas sobre o ventre, remonta a uma foto de imprensa, mostrando uma mulher hindu durante o bombardeio de Singapura agachada ao lado do filho morto. (17) Observações desse tipo formam o repertório dos atores.

$O$ signo gestual

De acordo com o projeto brechtiano, o signo gestual é considerado ao mesmo tempo como elemento do teatro épico natural $\mathrm{e}$ do teatro épico artificial. (18)

$\mathrm{O}$ ato da mimese, realizado pelo ator segundo um original, corresponde a um processo de pensamento - um pensamento corporal, pois a aprendizagem do ator consiste em transmitir o gestus a seu corpo inteiro (ST IV: 52) Ele mostra gestos que são, por assim dizer, os costumes do corpo (ST II: 101) Mesmo a fala é uma atividade corporal.ı Na peça Katzgraben (1953), de Erwin Strittmatter, a

(17) - Cf. a documentação fotográfica em Les Voies de la création théatrale, v. 2, Eds. du CNRS, Paris, 1970.

(18) - "Es besteht kein elementarer Unterschied zwischen dem natürlichen epischen Theater und dem künstlichen epischen Theater". (Die Strassenszene - Grundmodell einer Szene des epischen Theaters, in: ST 5: 69-86, cit. p. 85$)$. 
camponesa Kleinschmidt, sentada para descansar do trabalho e narrando, usa incessantemente o corpo para expressar sua opinião, suas sensações, seus sentimentos (ST VII: 119) Em seu conjunto, as definições brechtianas do signo gestual podem ser aproximadas da teoria semiótica: a fala como atividade corporal ou a linguagem corporal como fala constituem o objeto de estudo da cinética; (19) a linguagem focalizada numa dimensão de interação social, ocupando determinado "espaço gestual" (gestischer Bereich, ST VII: 44), é estudada por uma semiótica denominada proxemics. (20) No entanto, diferentemente dessas duas disciplinas, recém-constituídas e empenhadas em estabelecer unidades constitutivas mínimas, a poética brechtiana do discurso gestual, que abrange a ambas, trabalha com uma categoria extremamente flexível - o gestus - que visa a percepção da totalidade através do pormenor significativo. (21)

O código gestual, embora mais antigo, mais elementar, mais primitivo que o código verbal, recebeu sua descrição sistemática bem mais tarde (pelo menos do ponto de vista da ciência moderna) $\mathrm{Na}$ nossa cultura é de praxe reportar os vários sistemas sígnicos ao código verbal. Brecht coloca explicitamente o problema da tradutibilidade.

Durante o exílio nos Estados Unidos, elaborou junto com o ator inglês Charles Laughton uma tradução e uma encenação da peça Vida de Galileu. Informa Brecht: "O fato desvantajoso de um dos tradutores não saber alemão e de o outro saber só um pouquinho de inglês, exigiu desde o início a representação teatral como método de tradução" (ST IV: 230), Nessa experiência, Brecht representava tudo num inglês rudimentar ou mesmo em alemão, e Laughton por sua vez repetia a representação da mesma cena em inglês correto, de maneiras sempre diferentes, até Brecht poder dizer que ele tinha acertado. Diz Brecht: "Fomos obrigados a fazer aquilo que tradutores com melhor domínio da língua também deveriam fazer: traduzir ges-

(19) - Cf. Ray L. Birdwhistell, Introduction to Kinesics, University of Louisville Press, 1952; e Kinesics and Context: Essays on Body-Motion Communication, Penguin University Books, s.d.

(20) - Cf. Edward T. Hall, The Silent Language, Doubleday \& Co., New York, 1959; "A system for the notation of proxemic behavior", American Anthropologist 65 (5), 1963, p. 1003-1025; The Hidden Dimension, Doubleday, New York, 1966.

(21) - Outro projeto poético de linguagem gestual foi desenvolvido recentemente por Octavio Paz (Conjunciones y disyunciones, Mexico, 1969), com uma análise comparada do "SIGNO CORPO" nas culturas hindu, chinesa, mexicana e ocidental. 
tos. Pois a linguagem é teatral, quando expressa primordialmente o comportamento dos interlocutores entre si (ST IV: 230-231)

A mesma idéia aparece numa nota de Brecht sobre a "tradutibilidade de poemas": "Na tradução para uma outra língua, muitas vezes os poemas resultam seriamente danificados, quando se tenta traduzir demais. Talvez seja suficiente contentar-se com a transposição dos pensamentos e da postura do autor. Tentar transpor o que no ritmo do original é um elemento do gestus de quem escreve, nada mais. Sua atitude para com a linguagem - por exemplo, a invenção de novos modos de dizer, a colocação de determinadas palavras numa sintaxe desacostumada - é transmitida também quando se imita apenas essa atividade, sem deixar que o original prescreva o exato momento." (22)

Quando Brecht fala em "linguagem gestual", pensa em primeiro lugar na unidade entre gesto e palavra. A interrelação entre os dois tipos de signos pode-se fazer num duplo sentido: 1) Do gestus à palavra. Na discussão de Antígone com o coro dos velhos de Tebas (Brecht, Die Antigone des Sophokles, versos 748 e seguintes), evitou-se, antes de mais nada, o hábito segundo o qual os atores, antes de longas tiradas, se "abastecem" com uma emoção mais ou menos suficiente para todos os versos; a alternativa proposta por Brecht é evitar qualquer "paixão" antes ou depois da fala: "Caminha-se de verso para verso, e cada um deles é desenvolvido a partir do gestus da personagem" (ST VI: 34) .

2) Das palavras ao gestus. Em cada constelação social, postula Brecht, o indivíduo deve ser julgado segundo o que ele mostra de si e segundo o que faz - o que conta são os signos externos. A arte do ator baseia-se mais na comunicação gestual do que na expressão verbal: "também as palavras devem ser reduzidas a um gestus" (ST IV: 31 )

E o caso de frisar essa preponderância da série gestual, pois o estudo dos seus traços distintivos poderá esclarecer a sua capacidade comunicativa específica .

Um exemplo, tirado da esfera política, em que o gesto se mostra mais forte que a palavra é o de Hitler como argumentador (ST V: 95) A uma frase já pronta, declarada com um máximo de força vocal

(22) - "Die Übersetzbarkeit von Gedichten", in: GW 19: 404. - Às exp:essões grifadas corresponde, no original, sempre a mesma palavra: Haltung. Optei por uma tradução tríplice - postura, gestus, atitude - para marcar os diferentes aspectos do termo. 
como verdade inabalável e indiscutível, gosta de acrescentar uma conjunção causal, fazer uma pausa e enumerar razões. Várias dessas "razões" não possuem caráter de raciocínio, mas o gesto é o reforço que faz com que o dito se torne argumento. O que lhe importa é seduzir o espectador, por via de empatia, com essa postura-impostura de argumentador. Assim, não obstante certos erros de pensamento que possa cometer, a imagem transmitida é a de um orador que raciocina, que usa argumentos. Não por meio de palavras, mas apesar delas, contra elas - tudo isso por obra do gestus.

O que contribui para tal superioridade do gesto sobre a palavra não é apenas o seu caráter imagético, mas o elemento primitivo, corporal, desencadeador de reflexos - tudo o que facilita sua gravação na retina e nos músculos. Brecht recomenda que a encenação não se esqueça em nenhum momento que muitos dos acontecimentos e dos discursos são difíceis de entender de modo que se torna necessário expressar o sentido básico já por meio das posições e das posturas (ST IV: 236) Na peça Katzgraben, a camponesa Kleinschmidt coloca-se frente a Steinert, porque isso é uma pequena demonstração e porque assim ele grava melhor o que ela tem a lhe dizer Além disso, ela não precisará falar num tom demasiadamente rude, pois a postura só por si expressa suficientemente o ataque (ST VIII: 122) Elabora-se sempre um determinado gestus básico (Grundgestus), que vai além do sentido individual das frases (ST II: 75)

Sob este aspecto, a linguagem gestual de um Hitler e de um Brecht parecem aproximar-se de maneira inquietante; teria Hitler sido um ator épico? A diferença reside no fato de o líder fascista ter visado a empatia, ao passo que, no teatro épico, o gestus sempre implica na dimensão dialética da contradição e do estranhamento. $O$ ator deve marcar, antes de mais nada, os traços contraditórios da personagem: o herói, por exemplo, pode ser mostrado como sendo cruel contra o seu criado. Não é permitido ao ator omitir, em nome de uma representação mais cômoda, certos traços inviduais "que não calham", sacrificá-los a uma falsa imagem "integral" (ST IV: 21-22.

\section{$O$ processo de produção}

O teatro épico é uma oficina em que se elabora, a partir da matéria prima colhida na realidade imediata e nos "mass-media", o signo gestual que compõe o discurso estético. $\mathrm{Na}$ descrição da feitura do "Galileu de Laughton", Brecht esclarece que falará menos do produto acabado que do processo de produção (ST IV: 227) Suas informações podem ser vistas dentro da tradição de um Edgar Allan Poe, precursor com seu depoimento sobre a produção do texto poético, 
(23) embora aqui se trate da fabricação de um discurso gestual. Como Poe, Brecht permite um olhar atrás dos bastidores, um exame do instrumental técnico e do modus operandi. Como Poe, o teórico do "teatro da era científica" mostra que nada é deixado ao acaso ou à "inspiração", mas gesto por gesto é elaborado com a mesma precisão e lógica que as diferentes partes de uma demonstração matemática. Como Poe, Brecht parte da consideração do efeito, da repercussão sobre o público espectador: "O ator deve fabricar seus efeitos tecnicamente" (ST IV: 30)

O emprego inconsciente ou arbitrário dos recursos gestuais, frequiente no teatro ocidental, torna-se alvo da crítica de Brecht: "As posições no palco deveriam ser mantidas, enquanto não surgir razão premente de mudá-las; o desejo de variar não constitui razão premente. Ceder a ele acarreta rapidamente uma desvalorização dos movimentos no palco; o público deixará de procurar neles um significado especial, deixará de levá-los a sério" (ST VI: 64) A elaboração da linguagem gestual exige precisão, economia, objetividade: "O público precisa ter certeza de que um andar, um levantar-se, um gesto são significativos e que merecem atenção" (ST IV: 236) Se houver necessidade de mudar a posição, ela deve coincidir com a expressão de um momento significativo para a ação. Os momentos de mudança radical de posição são chamados pontos nodais da intriga (Drehpukte der Handlung, ST VI: 65) Na primeira cena de Mãe Coragem, o sargento examinando os rapazes Queijo-Suiço e Eilif sublinha um ponto nodal quando volta até Mãe Coragem, se planta na frente dela e pergunta: "Por que isso daí não quer prestar serviço militar?" (ST VI: 65) A recomendação de que tais movimentos não devem ser apagados por palavras simultâneas, mostra o valor autônomo atribuído ao signo gestual.

A sequiência de pontos nodais da intriga constitui a dimensão sintagmática da peça. Um filme feito da encenação de Homem por Homem (1931), registrando apenas esses pontos nodais, realçando assim o elemento gestual, evidenciava a capacidade do ator, Peter Lorre, de reproduzir justamente nas longas tiradas o significado mímico, inaudível, subjacente a todas as frases (ST II: 77) A dimensão paradigmática das encenações corresponde ao que poder-se-ia chamar de escolha do "gesto justo" Em toda cultura existe uma espécie de vocabulário gestual, um conjunto codificado de signos. Qual o comportamento do ator épico desse repertório?

Como toda língua, o sistema gestual também é sujeito a transformações. A dimensão diacrônica da mudança pode ser detectada

(23) - Cf. E. A. Poe, "The Philosophy of Composition" 
através de vários cortes sincrônicos. O interesse do teórico do teatro épico é atraído pelo teatro chinês, onde a conservação do repertório gestual, durante várias geraçōes, constitui um pano de fundo diante do qual se destacam as inovações. As mudanças das figuras de repertório não são imperceptíveis e gratuitas, como acontece frequientemente no teatro ocidental, mas se fazem sob o olhar crítico e memorioso do público (ST IV: 53-54) Falando a favor de um gestuário em constante evolução, Brecht recusa a estilização, em que a cada gesto e a cada entonação corresponderia um significado fixo (ST III: 194) Para evitar o comportamento esquemático, o ator épico se apresenta "de mãos vazias", como alguém disposto a reinventar a linguagem: "Para encontrar os gestos subjacentes às frases, experimenta outras frases, mais vulgares, que não contêm o significado em questão, mas apenas o gesto" (ST IV: 13)

A atitude oposta ao gesto típico ,sempre reiterado, automático, é o estranhamento. (24) O ator representa de modo que se vê, com a maior nitidez possível, a alternativa: seu jogo mostra apenas uma das variantes, mas faz imaginar as outras, também as contrárias. Ele diz, por exemplo: "Você me paga" e não diz: "Você está desculpado" $\mathrm{O}$ que ele não faz, deve estar contido e superado naquilo que faz. Deste modo, todas as frases e todos os gestos são decisões, a personagem fica sob controle e é testada. O termo técnico para o procedimento chama-se: fixar o A e não o B (Fixierung des Nicht: sondern, ST III: 153)

Os recursos técnicos para a fabricação do discurso gestual são vários. Um método bastante simples para produzir o estranhamento do gestus é separá-lo da mímica (ST III: 193) O ator coloca uma máscara e, observando sua representação no espelho, "escolhe" seus gestos. O próprio fato da escolha produz o efeito de estranhamento. Outros recursos são a imagem fotográfica (25) e o filme. Uma película feita de Helene Weigel durante a maquilagem mostrou, quando cortada, imagem por imagem uma expressão acabada em si e com significado próprio. Cada gestus deixava-se decompor no número de gestos desejado e qualquer uma dessas imagens estava perfeita, existindo por si e ao mesmo tempo para as outras. O que pareceu mais importante a Brecht foi que cada deslocamento de músculo evocava

(24) - Cf. "Kurze Beschreibung einer Technik der Schauspielkunst, die einen Verfremdungseffekt hervo:bringt", in: ST III: 155-177.

(25) - Cf. o trabalho de documentação fotográfica das encenações nos "livros-modelo": Antigonemodell 1948 e Couragemodell 1949. 
uma expressão psíquica perfeita. As pessoas às quais mostrava as imagens para opinarem, interpretaram-nas ora como expressões de ira, ora de alegria ou inveja ou compaixão. Mostrou-as também para a atriz explicando-lhe que ela precisava apenas conhecer seu repertório mímico-gestual para poder expressar os diferentes estados emotivos, sem necessidade de vivê-los cada vez (ST V: 149-150)

Fabricar sinteticamente a linguagem emotiva é o projeto de Brecht. Diferentemente de outras estéticas teatrais, como a de Stanislawski, a vivência das emoções não está em primeira plana. Tudo o que se passa no íntimo do ator deve ser exteriorizado, a emoção tem que se emancipar e constituir-se em signo gestual suscetível de aperfeiçoamento (ST III: 161) E melhor o ator aprender a negligenciar seus próprios sentimentos e procurar saber os dos outros. Mesmo os próprios estados emotivos ele conhece melhor quando lhe são apresentados como os de um outro (ST IV: 30) Um bom exercício consiste em um ator ensinar a representação do seu papel a um aluno, a um ator de sexo oposto, ao parceiro, a um cômico, etc. (ST III: 168) É muito instrutivo ver o próprio papel representado pelo outro, pois isto tende a desenvolver maior objetividade. Em suma, o conhecimento não visa as emoções individuais de um personagem por meio da empatia (Stanislawski), mas a interação social por meio de signos gestuais externos e objetivos.

\section{$A$ atitude ator: personagem}

A atitude do ator em relação à personagem-mensagem corresponde ao que a teoria da comunicação define como função emotiva. Ora, a postura do ator épico parece ser o exato contrário de uma atitude "emotiva", pois ele tenta achar o tom adequado para as expressões da personagem "com um mínimo de participação emotiva" (mit einem Mindestmass seelischer Beteiligung, ST IV: 21)

$\mathrm{Na}$ arte teatral chinesa, citada como modelar, o jogo do artista muitas vezes parece "frio" ao ator ocidental (ST V: 170-171) Tal "esíriamento" não impede que se representem acontecimentos de grande carga emotiva, porém sem exaltação. Em momentos de profunda excitação do personagem, o artista morde uma madeixa de cabelos, mostrando: esse homem está fora de si. Ateriormente, foi feita uma cuidadosa escolha entre vários signos possíveis: a raiva se distingue da indignação, o ódio da antipatia, o amor da simpatia, etc., mas o traço comum dos diversos estados emotivos é sua representação econômica. O ator ocidental, ao contrário, faz tudo para levar o seu espectador o mais perto possível da personagem e dos atos representados. Leva-o a colocar-se no lugar dele (sich einfühlen) e 
dedica toda sua energia a transformar-se o mais completamente possível na personagem representada. $O$ ator chinês renuncia à identificação total e cuida de não transpor as emoções da personagem para o espectador Quando a personagem sente compaixão, o espectador tem a liberdade de sentir nojo. A sensação de "esfriamento" resulta de uma concepção mais técnica e mais consciente da arte do ator. Quando representa, ele olha também para os seus braços e suas pernas, como que controlando o trabalho deles. Assim, o artista separa a mímica (representação do olhar observador) da linguagem gestual (representação do objeto), mas a última nada perde, pois a atitude do corpo age retroativamente sobre o rosto, transmitindo-lhe inteiramente sua expressão: " $O$ artista usou seu rosto como uma folha vazia a ser escrita pelo gestus do corpo" (ST V: 168-169)

Assim, a técnica do "esfriamento" é diametralmente oposta à técnica que visa a empatia. Condição básica para a produção do efeito de estranhamento é que o ator marque sua representação com um nítido gestus demonstrativo. Este é encontrado tanto na arte teatral chinesa quanto no teatro cotidiano. A demonstração do comportamento de outras pessoas acontece diariamente em inúmeras ocasióes: um indivíduo se divertindo a imitar o andar cômico de um amigo, as testemunhas de um atropelamento imitando, para os que chegaram depois, o comportamento do motorista e do ferido, etc. Nesses casos, os demonstradores usam uma certa empatia em relação às pessoas demonstradas, para apoderar-se de suas qualidades, porém não fazem nenhuma tentativa de envolver os espectadores em alguma ilusão.

No teatro épico, a renúncia à transfiguração total faz com que o ator apresente o seu texto não como uma improvisação, mas como uma citação (ST III: 159) Assumindo uma relação livre para com a sua personagem, o ator a faz falar e se movimentar, referindo-a apenas (ST III: 169) E como se ele falasse de memória, citando a personagem, como testemunha de um processo. Em outras palavras: o ator assume a atitude de um narrador (ST VI: 17) Nas anotações sobre o prelúdio de sua Antígone, Brecht observa que a narração deve ser despojada, não como se a narradora, Antígone, estivesse impressionada com os acontecimentos, mas como se tivesse a incumbência de relatá-los muitas e muitas vezes. Seu jogo teria então um caráter nitidamente "díctico" Como a passagem imediata da representação à narração e ao comentário é uma das características básicas do teatro épico, a tradicional oposição da teoria da perspectiva narrativa entre showing e telling deve ser reconsiderada.

Para provocar o estranhamento, Brecht indica três recursos a serem utilizados durante os ensaios: a transposição para a terceira 
pessoa - a menção explícita de indicações cênicas - comentários. $\mathrm{O}$ ator experimenta o seu papel ora na primeira, ora na terceira pessoa. (26) " $E u$ lhe disse a minha verdadeira opinião e falei. "; "Ele se emocionou, procurando alguma coisa com que pudesse me ferir e finalmente disse. " A justaposição dos dois modos de falar produz o efeito de estranhamento: o que foi falado no tom do emissor da mensagem é pronunciado no tom do receptor (ST IV: 33-34) Estranhada deste modo, a fala do ator implica ao mesmo tempo a sua opinião sobre a personagem.

A atitude auto-observadora do ator épico (27) traduz uma dupla vigilância: em relação ao código emotivo corrente, reforçado pelo hábito, às possibilidades de sua ruptura .

\section{$A$ atitude ator: - público}

A atitude do ator em relação ao espectador corresponderia ao que a teoria da comunicação chama de função conativa. "A relação do ator para com seu público", diz Brecht, "deve ser a mais livre e a mais direta possível; ele tem algo a lhe comunicar e a mostrar, e essa atitude deve estar subjacente a tudo" (ST III: 166-167 e IV: 28-29) No teatro tradicional, o ator se interdiz de olhar diretamente para os espectadores, ele faz de conta que não estão presentes, imaginando uma quarta parede; no teatro épico, dirige-se a eles diretamente. Quando representa, olha de vez em quando para o espectador como querendo dizer: "Veja bem, como age aquele que agora vou apresentar a você" - esta é a atitude básica (Grundhaltung, ST IV: 29)

O ator expõe o material de que são feitos os acontecimentos. Antes de mostrar como alguém comete uma traição, é tomado por ciúmes ou conclui um negócio, o ator olha para o espectador, como se quisesse dizer: "Atenção, agora este homem vai cometer uma traição, e assim ele age; assim ele fica quando está devorado por ciúmes", etc. (ST V: 275) Deste modo, a apresentação dos atores tem uma atitude demonstrativa que faz com que as emoções sejam submetidas ao julgamento do espectador (ST V: 78-79)

A renúncia quase total ao recurso da empatia não significa renúncia a influenciar (ST IV: 79) A representação do comportamento humano na interação social deve justamente influenciar e intervir no comportamento do espectador (eingreifend beeinflussen). Tais inter-

(26) - Cf. Brecht falando de si próprio como “der Stückeschreiber" "o escritor de peças"

(27) - "Der Artist sieht sich selber zu", ST III: 170 e V: 169-170. 
venções inevitavelmente desencadeiam efeitos emotivos; eles são previstos e devem ser controlados. Portanto, quando Brecht fala da atitude de fazer simples propostas (ST III: 159), deve-se entender que subjaz um projeto de controlar a decodificação feita pela platéia.

Uma parte desse controle cabe à música gestual (ST III: 276277) (27a) A música não apenas acompanha, ela comenta. Brecht considera exemplar a solução de Eisler na encenação do Galileu: o compositor relacionou os acontecimentos da cena carnavalesca desfile mascarado das guildas - com uma música triunfante e ameaçadora, mostrando a interpretação subversiva dada pelo povo às teorias astronômicas do cientista. Assim, a música pode ser tomada de posição (ST VII: 54)

Quando Brecht se serve de elementos dionisíacos (música, carnaval), toma-lhes emprestado o riso, a comicidade, o grotesco, não a embriaguez, o delírio, o misticismo. O dramaturgo desconfia de "movimentos mágicos" no palco (ST VII: 37) e não tenciona colocar o seu público em estado de transe. O ator não é uma espécie de sacerdote numa liturgia em que qualquer perturbação seria tabu (ST V: 253) Brecht se distancia de estéticas teatrais marcadamente neodionisíacas. Advertido pelo precedente das encenações fascistas em que teatro, festa, carnaval, liturgia, propaganda e política se misturavam indiscriminadamente, mas sempre com a função de tornar impotente o pensamento crítico - Brecht tem motivos de desconfiar das tentativas de criar "atmosfera", de produzir "ambiente", do "natural" ensaiado, da "libertação dos complexos", dos "campos hipnóticos" em suma, de tudo o que é "mágico" e "fascinante"

Como um dos meios técnicos para neutralizar esses procedimentos é indicada a iluminação muito clara do palco, uma vez que uma iluminação crepuscular, junto com o black-out da platéia oculta ao espectador a visão do seu vizinho e o esconde a ele próprio, retirandolhe assim muito de sua sobriedade (ST III: 241) Visibilidade das fontes de luz — visibilidade das fontes de informação. Tornar transparente a técnica, talvez seja esta a característica principal da arte moderna. Ela aplica isso em causa própria, desmistificando o seu processo de criação, mas ao mesmo tempo lança luz sobre os processos de fabricação dos demais discursos, das demais retóricas, das demais técnicas de persuasão.

(27a) - Ver também ST III: 281-285: "Uber gestische Musik" 
O público dos Escritos sobre Teatro foi, durante os anos 1933 a 1948, um público ideal e abstrato: ideal enquanto categoria sociológica no sentido weberiano, e abstrato na medida em que o Escritor exilado estava separado do seu público conterrâneo. Com a volta de Brecht para a Alemanha, em 1949, e com seu trabalho no Berliner Ensemble, até 1956, começa uma outra fase de atuação. Mas o lugar estava histórica e sociologicamente transformado, o que fez com que a atuação do teatro de Brecht dos anos 1950 para cá se tornasse extremamente complexa. Esses aspectos serão considerados num próximo estudo. 